\title{
Una insensatez de dibujo animado. Las formas del nonsense en Viaje olvidado, de Silvina Ocampo*
}

Fecha de recepción: 29 de septiembre de 2017

Fecha de aprobación: 15 de enero de 2018

\section{Resumen}

Este trabajo se propone analizar las formas del nonsense en Viaje olvidado, el primer libro de cuentos de Silvina Ocampo. En estas narraciones, una radical indiferencia por el sentido conduce a la aparición en el discurso de un mundo disparatado, en el que se ligan infancia y sinsentido. La superficialidad, la falta de emoción o la displicencia con que se cuentan determinados sucesos, le imprimen al relato un giro humorístico por el que la narración se precipita hacia la lógica del dibujo animado. En cuanto lo inaudito irrumpe, trastornando la relación con la lengua, el humor marca el paso del sentido al nonsense.

Palabras clave: Viaje olvidado; Silvina Ocampo; nonsense; infancia, dibujo animado.
Citar: Biancotto, N. (enero-junio de 2018). Una insensatez de dibujo animado. Las formas del nonsense en Viaje olvidado, de Silvina Ocampo. La Palabra, (32), 85-98. doi: https://doi.org/10.19053/01218530.n32.2018.8166.

\section{Natalia Biancotto}

Profesora en Instituto de Estudios Críticos en Humanidades UNR - CONICET. Doctora en Humanidades y Artes con mención en Literatura (FHyA, U.N.R.) y Magíster en Literatura Argentina (FHyA, U.N.R.). Becaria posdoctoral del CONICET.

biancotto@iech-conicet.gob.ar

* Artículo de reflexión producto de investigación doctoral. 


\section{Abstract}

This paper analyzes nonsense forms in Viaje olvidado [Forgotten Journey], Silvina Ocampo's first book. In these stories, a radical disregard for rational and common sense leads to the appearance of a insane world in which childhood and nonsense are linked. Certain events are narrated with a superficiality, lack of emotion and indifference that introduce a humorous twist to the story, bursting into the logic of cartoon. Humor marks the passage from sense to nonsense, as these unprecedented bursts disrupt the relationship with language.

Key words: Viaje olvidado; Silvina Ocampo; Nonsense; Childhood; Cartoon.

\section{Un délire de bande désinée. Les formes du non-sens dans Viaje olvidado [Le voyage oublié] de Silvina Ocampo.}

\section{Resúmè}

Dans ce travail nous analyserons les formes du non-sens dans Viaje olvidado, le premier recueil de nouvelles de Silvina Ocampo. Dans ces récits, l'indifférence radicale à la production de sens permet l'apparition d'un monde absurde au sein du discours dans lequel l'enfance et le non-sens sont liés. La superficialité, le manque d'émotion ou l'indifférence avec laquelle certains événements sont racontés, marquent une tournure humoristique dans l'histoire à travers laquelle le récit se précipite vers la logique de la bande déssinée. Lorsque l'absurde fait irruption il bouleverse la rapport à la langue. L'humour met en évidence le passage du sens au non-sens.

Mots-clés: Viaje olvidado; Silvina Ocampo; enfance; non-sens; bande déssinée. 
A cualquiera que lea los relatos de Viaje olvidado le sobreviene, con mayor o menor intensidad, la sensación de estar ante un librito de viñetas. A ese mismo lector, cualquiera podría sobrevenirle también, en algún momento, la confusa idea de haberse encontrado con una serie de dibujos, en un libro sin dibujos. Porque en muchos de los cuentos la narración asume formas plásticas y trazos infantiles, cuando no recuerda, lisa y llanamente, a los dibujos animados. A esa cualidad "emparentada con los dibujos animados, pero en un territorio que depende de otra jurisdicción", se refirió la reseña de Victoria Ocampo (1937, pp. 119-120) -una precisión interesantísima que extrañamente ninguna de las lecturas posteriores retomó para extender, ni siquiera para interrogar-, en una dirección que buscaba pensar las implicancias narrativas que se derivan de la peculiaridad con que en estos cuentos "los personajes son cosas y las cosas personajes, como en la infancia" ( $p$. 120).

¿Cómo es narrar con la lógica de los dibujos animados? Parece verosímil que una escritora que se inicia tardíamente en la literatura, luego de abandonar, o soslayar, su vocación por el dibujo -su interés siempre fue dibujar antes que pintar-, haya comenzado a escribir con esta pregunta. Aunque nunca lo comprobaremos (después de todo, ¿acaso importa?), saber que Ocampo dibujaba y que nunca dejó de hacerlo, es apenas un dato más para sumar a la contundente evidencia de la asociación feliz que ocurre entre la narración y los modos del dibujo en los relatos de Viaje olvidado.

Noemí Ulla (1989) vinculó ciertos rasgos de estos cuentos con la pintura impresionista, al proponer la posibilidad de que la autora "haya enlazado sus propias experiencias con la plástica, anterior a su decisión de escribir" (p. 389)1 . Pero, nos preguntamos algo diferente cuando decimos «¿cómo es narrar con la lógica de los dibujos?». Nos preguntamos por el atributo plástico de la narración, y por el modo en que su plasticidad deviene en, o viene junto con, una indiferencia por el sentido. Plasticidad e indiferencia son los avatares de un relato que esquiva la profundidad del sentido.

A la superficialidad, la falta de emoción o la displicencia con que se cuentan determinados sucesos hacia los que uno esperaría un tratamiento "profundo", remite la reseña de José Bianco (1937) cuando asocia la singularidad de estos cuentos, no ya con el dibujo animado, como Victoria, sino con un pariente cercano: el relato infantil.

Esta atmósfera propicia a la magia -señala Bianco- surte efecto desde el primer relato. El lector se habitúa a ella sin violencia, y poco después siente el mismo asombro de los niños ante las peripecias comunes narradas en los cuentos, en tanto que los sucesos milagrosos le parecen el colmo de la naturalidad. Nada más natural que Eponina abandone la lectura de "la moda elegante", suba al altillo de su casa, encuentre a su hijo muerto en un baúl, y murmure abrazada a su sirvienta: "Niño de cuatro años, vestido de raso de algodón color encarnado. Esclavina cubierta de un plegado que figura como olas ribeteadas con un encaje blanco. Las venas y los tallos son de color marrón, verde mirto o carmín." Nada más natural [...] que Clodomira sienta deseos de aplaudir y sonría recordando sus primeras angustias en el circo, cuando sus dos hijos acróbatas se arrojan desde un tercer piso y caen aplastados contra el suelo del patio: "ahora estaba acostumbrada a esas cosas". (p. 148).

Que una madre sobreviva a su hijo es, se suele decir, antinatural. Que una madre presencie la muerte de su hijo resulta, además de antinatural, el colmo del horror. Al menos, esto dicta el

Matilde Sánchez (1991), por su parte, anota: “Viaje olvidado es una colección de cuentos de marcado tono impresionista” (p. 13). 
sentido común ${ }^{2}$. Pero, que una madre presencie la muerte de su hijo y, con absoluta naturalidad, sonría, aplauda o hable de moda es, a todas luces, el colmo del disparate. Un sinsentido, algo que el sentido común no puede entender. Se podrá objetar, por ejemplo, que Eponina detestaba a sus hijos y que, por lo tanto, encontrar muerto a uno de ellos no es, en su caso, necesariamente una desgracia. De acuerdo, pero de cualquier manera el sinsentido no desaparece: antes bien, se exacerba. Una madre que detesta a sus hijos al punto de regocijarse con su muerte es un planteo que, con lógica feroz, lleva el disparate al extremo de lo impensable. Y sin embargo, se trata justamente del hijo "al que más había ambicionado subir sobre sus faldas" (Ocampo, 2005, p. 62).

Si volvemos al punto cero, entendemos que es en la muerte del hijo donde radica el verdadero sinsentido, y que cualquier cosa que se haga después, reír, aplaudir, incluso llorar o desesperarse, no esclarece ningún sentido. La desgracia pertenece al orden del sinsentido de la vida. Reír ante la muerte podría ser entonces un modo de responder al sinsentido con el sinsentido, lo cual, dicho así, suena estrictamente lógico. La lógica extrema, que en efecto tiene esa consigna, define la ética del sinsentido: el ejercicio de la extravagancia en medio de la desgracia. Ejercer con desatino el desatino del mundo: nada más coherente $\mathrm{y}$, por lo tanto, nada más loco. Lo dice mejor un poema de Emily Dickinson (2011): "Much Madness is divinest Sense- / To a discerning Eye — / Much Sense - the starkest Madness_-" (p. 116); en la traducción de Silvina Ocampo (2013): "Mucha locura es juicio divino- / para el ojo más sagaz- / mucho juicio- la más estricta locura" (p. 125).

¿En qué consiste la locura o el desatino de los personajes de Viaje olvidado? ¿Está loca la narradora de "Cielo de claraboyas" cuando al ver "una cabeza partida en dos" habla de flores, moños y soldaditos (Ocampo, 2005, p. 9)? ¿Qué clase de locura es la que lleva a Eponina, de "El retrato mal hecho", a ver a su hijo muerto como un modelito en una revista de costura? ¿Cuál, la que hace sonreír a Clodomira ante "el gesto maravilloso" de sus hijos, "Los funámbulos", al dar el "salto glorioso" por el que caen aplastados contra las baldosas (p. 83)? ¿Qué loca en- fermedad afecta al paciente de "Diorama", cuando cree ver en un cuarto vacío a una amante que lo cuida? ¿Qué falta o qué exceso de juicio hace que $\mathrm{Au}-$ relia, la hija díscola de "La familia Linio Milagro", se interne entre las llamas sólo para tocar el piano "imperturbable en la noche" (p. 167)?

En una primera aproximación, lo que opera en estos casos es un abandono del sentido común, dada su incompetencia para una vida que se ha sumido en la desgracia. Cuando el infortunio irrumpe, el sentido común ya no sirve para nada: no se puede seguir viviendo de acuerdo con sus pautas. El sentido común permite habitar el mundo de las cosas razonables; resulta útil siempre que la vida muestre su cara comprensible, siempre que el mundo sea mundo. Pero cuando el infortunio aparece, el mundo se vuelve inhabitable, revela su sinrazón, su otra cara incomprensible. Es decir, se vuelve real. Con frecuencia esa otra cara es la de la muerte -lo otro por excelencia-, pero no es la única. Cada vez que irrumpe lo inquietante, en cualquiera de sus formas -la enemistad de las cosas, los terribles ojos sueltos de la muñeca ciega ("Día de santo"), la enfermedad como

\footnotetext{
2 El estudio de Susan Stewart (1989) sobre el nonsense, se fundamenta en una problematización del vínculo entre lo que consideramos «sentido común» y «sinsentido» en el plano del discurso. Stewart considera el sentido común [common sense] como "una organización del mundo, un modelo de orden, integridad y coherencia lograda en la vida social. Y el sinsentido [nonsense] es considerado como "una actividad por la que el mundo se desorganiza y reorganiza". Aclara, además, que no ve el sentido común "como un terreno estable para el proceso social, sino como una realización continuamente en curso de ese proceso-los actos del sentido común darán forma a los actos del sinsentido y éstos a su vez darán forma a los actos del sentido común" (p. vii.) (La traducción es mía).
} 
extrañeza de la vida ("Diorama", "El corredor ancho de sol")- el mundo amenaza con caerse del otro lado de la razón. Sobre ese delgado límite caminan los cuentos de Viaje olvidado, bordeando la frontera imposible entre sentido y sinsentido, razón y locura, lenguaje y mudez. De este movimiento acrobático invisible habla Alejandra Pizarnik (1994), cuando dice que los cuentos de Silvina Ocampo se trasladan "al plano de la realidad sin haberlo dejado nunca" y, al mismo tiempo, "al plano de la irrealidad sin haberlo dejado nunca" (p. 415).

Sin dejarnos confundir por las resonancias del término "irrealidad", por el reenvío que propicia hacia la extranjería de "lo fantástico", sabemos que ese lado "otro" no es más que la sinrazón de lo real. "También el mundo trivial permanece reconocible -puntualiza Pizarnik-, aunque extraño y transfigurado: de súbito se abre y es otro, o revela lo otro, pero el pasaje de la frontera es enteramente imperceptible" (p. 415). Despegado de su sentido habitual, el mundo desnaturalizado conlleva la desnaturalización del discurso. Aunque no se trata de una relación de causa-consecuencia, sino de fenómenos concomitantes: el mundo loco se crea cada vez que el discurso se enloquece.

La voz de "Cielo de claraboyas" resulta particularmente elocuente de la aparición en el discurso de un mundo disparatado. No parece haber modo más apropiado de comentar este relato que referirse a las imágenes del mundo "patas arriba" cuando lo que se cuenta es precisamente la breve historia de "una familia de pies" que alguien ve "vivir a través de los vidrios" de la claraboya (Ocampo, 2005, p. 7). Desde luego que, el recurso al punto de vista y la figura de la metonimia tiene aquí una importancia insoslayable, pero de ningún modo se agota en ellos la extrañeza involucrada en la construcción de las imágenes ni en la narración de los hechos. Es evidente el juego retórico puesto en marcha al hablar de serpientes en referencia a los cables del ascensor, o de "voces que rebotan como pelotas" ( $p$. 7), o de "pies aureolados como santos" (p. 7). No obstante, en medio de esa proliferación de imágenes intensas aparece, de pronto, un detalle que nos hace desconfiar: Celestina en camisón "saltando con un caramelo guardado en la boca" (p. 8). Si hasta el momento quedaba claro que se describía lo ocurrido en la "casa misteriosa" (p. 7) según podía percibirlo alguien desde el hall "con cielo de claraboyas" de la casa de abajo, ¿cómo supo ese alguien que la nena cuyos pies veía saltar la cuerda tenía un caramelo en la boca? ¿Cuánto más imaginó esa voz narradora? En adelante, sospechamos en ella algún incierto deseo que, como la tentación de esconder un caramelo en su relato, llevar a contar que un reloj crece "como un árbol a la hora de acostarse" (p. 7), o que la "pollera disfrazada de tía" es "un diablo negro" con "garras" y "alas de demonio" (p. 8). Lo que sucede entonces es la aparición en el lenguaje de un mundo extravagante, empapado de los términos del cuento infantil y del dibujo animado.

Cuando los niños inventan cuentos -dice Benjamin (1989) sobre los modos de relación de la sensibilidad infantil (la que está operando acá, más allá de que sea o no un niño quien narra) con las imágenes visuales del relato-, son escenógrafos que no admiten la censura del 'sentido' [...] la fantasía del niño se hunde en sus propios ensueños... lo hace salir de sí mismo. (p. 54).

Ese mundo insensato aparece incluso antes de que se precipiten los acontecimientos que rodean a "la cabeza muerta" (Ocampo, 2005, p. 9). Las que se precipitan son, en rigor, las imágenes que, como señala Judith Podlubne (2013), ahuecan, enmudecen el sentido:

Como muchas veces en Silvina Ocampo, aunque con una estridencia y una proliferación particulares en esta oportunidad, el torrente tropológico del lenguaje estalla y arrastra la claridad del sentido hacia el límite de sus posibilidades. La precipitación 
de las imágenes sobreactúa lo dicho y esa sobreactuación hueca, que es marca del hundimiento subjetivo de quien narra, da lugar al retorno de un resto perdido de infancia, deja que ese resto se escuche en el enmudecimiento del sentido que provoca la coexistencia fugaz e indeterminada del horror y el goce. ( $p$. 102).

Esa coexistencia de horror y goce provoca una cierta incomodidad que, no en pocas ocasiones, se ha caracterizado en términos de crueldad (Balderston, 1983). Pero, ¿son en verdad incompatibles las imágenes felices con el horror? Aun haciendo a un lado la posibilidad, para nada remota, de encontrar belleza en las imágenes más terribles, lo que ve la voz narradora es un dibujo sin moral, que no sabe de las incompatibilidades que censura el buen sentido. El aluvión de formas radiantes que estalla "como un trueno que rompe un vidrio" (Ocampo, 2005 , p. 9) se lleva consigo el sentido y entonces ocurre que:

Despacito fue dibujándose en el vidrio una cabeza partida en dos, una cabeza donde florecían rulos de sangre atados con moños. La mancha se agrandaba. De una rotura del vidrio empezaron a caer anchas y espesas gotas petrificadas como soldaditos de lluvia sobre las baldosas del patio. (p. 9).
Allí donde, con mayor intensidad que nunca, la narración acopia superficies sensibles capturadas por una sensación ocurre el olvido del sentido, la suspensión del juicio: la epifanía del dibujo. Porque lo que maravilla a la voz narradora es lo que, a través de la transparencia de la claraboya, se dibuja en el vidrio, la mancha que se agranda, la forma petrificada de la gota. Le sobreviene la aprehensión por los colores y las formas que, según Benjamin (1989), es propia de la fantasía infantil (p. 59), y que se interesa más por el brillo que estas destellan y las resonancias de sentido que emanan que por aquello que pasa. Es el momento en el que, como definió Podlubne (2011), los personajes y las voces narrativas caen en el "olvido de sí mismos" (p. 290) que les trae un resto perdido de infancia. Ese resto, que por definición es mudo, puede, sin embargo, brillar en la superficie de un dibujo nonsensical, que no dice nada y no sirve para nada. Ver, como en el famoso cuadro de Magritte, "soldaditos de lluvia" en las gotas de sangre que caen del techo no dice nada sobre la muerte de la nena, no sirve para entenderla, sencillamente porque no sabe nada de esa muerte. "Allí donde la pulsión invade e imprime la relación con la lengua -escribe Julia Kristeva-, el humor [da el] paso del sentido al [non-sens]" (citado en Pollock, 2003, p. 51). El disparate estremece la len- gua narrativa con el humor que supone pasar la tragedia por un tamiz insensato. En ese giro humorístico hacia el sinsentido, que remonta todos los sentidos para suspenderlos en la superficie, consiste la lógica del juego infantil y del dibujo animado.

Los niños son duros y están alejados del mundo -dice Benjamin (1989), y a continuación cita a Mynona-: “... Los pequeños se ríen de todo, aun de los lados sombríos de la vida; precisamente, esa hermosa extensión de la alegría hace que su luz alcance zonas por lo general privadas de ella [...] Logrados atentados terroristas en miniatura, contra príncipes que se parten en dos, pero pueden curarse: grandes tiendas que sufren incendios, robos y hurtos, muñecos-víctimas que pueden sufrir las muertes más diversas, y sus correspondientes muñecos-verdugo, con todos los instrumentos especiales, la guillotina y la horca..." (p. 66).

Así es como se manifiesta lo otro, inquietante y desatinado, con humor de dibujo animado. Quien observa se desentiende del sentido y se aboca, no a cualquiera de los actos que se juzgarían coherentes en el testigo de una tragedia (correr a socorrerla, llamar a alguien, desesperarse de alguna manera), sino a perder el tiempo, a dejarse atravesar por ese hueco en el tiempo del mundo habitual que abre la infancia. Perder el tiem- 
po, perder la coherencia, perder el sentido, no como acto de la voluntad, sino como producto de un deslizamiento imperceptible hacia la pura indiferencia. Si esa pérdida es inimputable a su voluntad, ¿será posible amonestarla en nombre de la crueldad?

Ese "perderse en sí mismas" (Podlubne, 2013) que afecta a las voces narrativas, se manifiesta como una salida del sentido común, imprevista y fugaz. Una suerte de súbito regocijo, una alegría triste que destella en la superficie, sobre un fondo de angustia. ¿Tiene algo que ver este regocijo con el de quien, al observar cómo tropieza el payaso, ríe sin preocuparse por si se habrá lastimado? Es precisamente en la despreocupación del-llamémosle por ahora- «regocijo» que esa indiferencia del sentido, que de pronto irrumpe, se parece a la risa: sale, irresistible y repentina, como un espasmo involuntario. Pero, no es regocijo sino tal vez «arrebato» la palabra que estamos buscando. La súbita e involuntaria aparición de la falta de razón, de la insensatez. La fugaz ocurrencia de un arrebato que deja al personaje indiferente a la razón, al logos, al lenguaje. ¿Será por eso que en estos cuentos la infancia tiene un destino nonsensical?

“LLa voz de quién -se pregunta Podlubne (2011) - vería en una muerte atroz las imágenes gozosas de un dibujo y un florecimiento?" (p. 101). Esa voz es, ciertamente, la del sinsentido en tanto "locura inimputable", como la llama Sergio Cueto (2008), y que consiste en la "salida sin retorno como pura pérdida de sí” (p. 24). Salirse de sí para ver desde el otro lado, donde las cosas no tienen profundidad. La mentada reunión de crueldad e inocencia solo es tal a fuerza de indiferencia. En rigor, lo que ocurre en esa salida sin retorno no puede juzgarse ni cruel ni inocente: a ella le compete el desatino de suspender en el aire todo tipo de juicios. No hay justificación intelectual para el gozo insensato de esas imágenes que brotan como un instante de gracia en medio de la desgracia.

Ahora bien, si la respuesta gozosa ante el espectáculo de una cabeza partida en dos resulta desconcertante, vale preguntarse también, en cualquier caso, qué palabra, qué gesto, qué reacción, sería capaz de reflejar o, al menos, de estar a tono con lo que acaba de ocurrir. En esa encrucijada irremediable, una voz infantil traza un dibujo. Narra, así, el movimiento tenso de la escena con la inmovilidad y discontinuidad de la viñeta, y, de alguna manera, insiste en contar aquello que ocurre en un fuera del tiempo.

Esa voz hace "gárgaras de risa", como dice Ocampo en otro cuento, y así convierte lo que no puede ser dicho en dibujo: una flor, un color, un soldadito de lluvia. El sinsentido irrumpe entonces con la inocencia, solo aparente, del dibujo animado. El grado de irrealidad e insensatez de la escena, se dirime de acuerdo con la verosimilitud del dibujo animado, donde lo terrible no deja de ocurrir bajo la forma hechizante de la imagen. Lo que no hace más que aumentar, paradójicamente, la convencionalidad del registro discursivo. Quiero decir, esa voz parece convencionalmente aniñada $\mathrm{y}$ feminizada. Me pregunto si la sucesión de diminutivos, mezclados con nubes, moños y flores, es lo que lleva, por la fuerza de los estereotipos, a pensar que posiblemente sea una niña la dueña de esa voz. Si el poder de los discursos cristalizados es aplastante, parece que el peso más fuerte lo tiene, no obstante, el registro melodramático y el campo semántico del cuento de hadas y el relato infantil (de los dibujos y no). Las "alas de demonio", las "garras", los botines de "diablo" negro, la "voz negra", la pollera negra: figuras del miedo y colores oscuros -el negro y las sombras- para delinear, prototípicamente, a la "mala de la película" (la clásica madrastra malvada, la "institutriz perversa", [Ocampo, 2005, p. 8]), en contraste con las nubes y moños que rodean a Celestina, los colores verdes, la "risa de pelo suelto" (p. 9) y los pies desnudos, siempre al compás de la caja de música. La semblanza del cuento de hadas y el dibujo animado opera bajo esas for- 
mas, esos dibujos, esos colores, sus movimientos y contrastes. Ellos protagonizan la acción. Pura plasticidad, chispazos de luces, colores y sombras, formas blandas y cambiantes: la narración danza en la sintonía de los dibujos y no se demora en juicios, no se sale de la superficie del baile.

$\mathrm{Si}$, apartando los prejuicios, no podemos afirmar que sea una niña la que narra, es porque la narración está a cargo de una voz sin edad, sin emoción, casi diríamos, sin humanidad. Una voz sin atributos, o con los atributos negativos de la infancia: imprecisión, inseguridad, indeterminación. En relación con ellos, Jeanne Marie Gagnebin (2004) define el modo de la percepción infantil a partir de "tudo o que a torna, aos olhares dos adultos, ingênua, crédula, incompleta e canhestra." (p. 82) ["todo lo que la torna, a los ojos de los adultos, ingenua, crédula, incompleta, torpe." (Traducción mía)]. Se refiere, además, a dicha "incompetencia infantil" como "reveladora de uma verdade que os adultos não podem nem querem ouvir [...] e que é reforçada por uma outra incapacidade infantil: a de não entender 'certo' as palavras, estes mal-entendidos infantis que nem sempre são engraçados" ["reveladora de una verdad que los adultos no pueden ni quie- ren oír $[\ldots]$ y que es reforzada por otra incapacidad infantil: la de no entender correctamente las palabras, estos mal-entendidos infantiles que no siempre son graciosos"] (p. 82). La "inhabilidad", junto con "todo lo que escapa a la soberanía del sujeto consciente", dice Gagnebin, marca "profundamente al niño que no adquirió la 'seguridad' del adulto" (p. 83). En un sentido muy afín al de estas afirmaciones, Susan Stewart (1989) caracteriza al nonsense como un lenguaje negativo:

Nonsense becomes a negative language, the language of an experience that does not count in the eyes of common-sense discourse. Nonsense is an impediment, an infirmity, to such discourse, for nonsense confuses the proper schedule for "time's marching on". Nonsense wastes our time. It trips us up. It gets in the way. It makes a mess of things. (p. 5) [El nonsense se vuelve un lenguaje negativo, el lenguaje de una experiencia que no cuenta a los ojos del discurso del sentido común. El nonsense es un impedimento, una debilidad, para tal discurso, puesto que el nonsense confunde el cronograma adecuado de 'la marcha del tiempo'. El nonsense nos hace perder el tiempo. Nos hace tropezar. Se mete en el camino. Crea un desorden. (Traducción mía)
El lenguaje del nonsense es, para el sentido común, una pérdida de tiempo que, como tal, irrumpe, igual que el espasmo involuntario de la risa, cuando el tiempo y el sentido se ahuecan en indiferencia. Tal vez el nonsense, el dibujo animado y el juego infantil se junten en ese lugar de la inutilidad que es el de la infancia.

Como lectores, esa narración insensata nos hace perder el tiempo, nos hace perder el hilo de la historia. ¿Qué pasó, a fin de cuentas, con Celestina? Si a la voz que narra esto le es indiferente, ¿por qué no intentar leer en la clave de la indiferencia? Como afirma Jacques Lacan a propósito de Lewis Carro11, la estructura es la que domina la historia ${ }^{3}$. Esta última permanece indefinida, como se constata, por ejemplo, en el " ¡Voy a matarte!" (Ocampo, 2005, p. 9) que grita la voz negra: ¿es en verdad una amenaza asesina o simplemente un lugar común del enojo, de esos que usamos livianamente, confiados en el valor retórico que el discurso cotidiano le atribuye? Asimismo, ¿a qué atribuir, junto a la pollera que vuela en torno de la cabeza muerta, la presencia de "un fierro [que] golpeaba con ritmo de saltar a la cuerda" (p. 9)? No se nos dice quién lo golpea (¿será la "institutriz perversa"?), ni adónde ni contra qué.

3 En su "Homenaje a Lewis Carroll", Lacan escribe: "la historia es dominante, pero no es la única dimensión: la estructura la domina. Se hacen mejores críticas literarias cuando se sabe eso." (1966). 
La estructura del relato impone, por sobre la historia, la fuerza de la incompletud y la impasibilidad. Lo que falla, lo que está dislocado, lo que no encuentra su lugar propio es el sentido común. Pero eso no significa subversión: no es una inversión ni voluntaria, ni provocadora, ni irónica del sentido. Se trata de permanecer en la superficie del sentido, de permanecer indiferente a la profundidad. De percibir las situaciones sin hacerlas pasar por la "luz" de la razón, que las organizaría, les conferiría coherencia, las llenaría de relaciones de causas y consecuencias. O bien: la tía le pegó con el florero, en consecuencia está muerta; por ende: la tía la mató ${ }^{4}$. O bien: la nena se cayó mientras jugaba, a causa de la caída se golpeó la cabeza, y el golpe le ocasionó la muerte.

El personaje, sin edad, habla de lo que ve sin hacer conexiones causales, sin pensar en las consecuencias de lo ocurrido, sin atender a las implicancias: como si fuera un habla sin razón, como si no tuviera o no prestara atención al logos ordenador, un habla imposible, en definitiva, $\tan$ imposible como pensar en un habla infantil, el habla del que no habla. Pero la que no habla allí es la razón: ha- bla la sin-razón, el sin-logos, el sin-sentido. ${ }^{5}$

Celestina muere pero, al final, queda de ella la viñeta que la congela para siempre en un instante de gracia:

Celestina cantaba Les Cloches de Corneville, corriendo con Leonor detrás de los árboles de la plaza, alrededor de la estatua de San Martín. Tenía un vestido marinero y un miedo horrible de morirse al cruzar las calles. (Ocampo, 2005, p. 9).

En cierto modo, no puede morir. De acuerdo con la impasibilidad y el afán de reiteración de esa imagen final, al menos, no le es dado morir. Repitiendo movimientos circulares ("alrededor de la estatua de San Martín") al compás de los acordes de Les Cloches de Corneville, que son los de las viejas cajas musicales, el dibujo final de $\mathrm{Ce}$ lestina queda superpuesto a su última imagen previa al desastre: "Los pies desnudos saltaban siempre sobre la cuerda ovalada bailando mientras cantaba una caja de música con una muñeca encima" (p. 8). Celestina se muñequiza y queda girando eternamente imperturbable, como la bailarina sobre la caja de música. En el final, triunfa la repetición de la inutilidad, que es la ley común al juego, a la infancia y al dibujo animado. Benjamin (1989) se refiere a esta "gran ley" que,

[...] por encima de todas las reglas y ritmos aislados, rige sobre el conjunto del mundo de los juegos: la ley de la repetición. Sabemos que para el niño esto es el alma del juego, que nada lo hace más feliz que el "otra vez". El oscuro afán de reiteración no es menos poderoso ni menos astuto en el juego, que el impulso sexual en el amor. No es vano creía Freud haber descubierto en él un "más allá del principio del placer". En efecto, toda vivencia profunda busca insaciablemente, hasta el final, repetición y retorno, busca el restablecimiento de la situación primitiva en la cual se originó. [...] no han de ser dos veces, sino una y otra vez, cien, mil veces. Esto no sólo es la manera de reelaborar experiencias primitivamente terroríficas mediante el embotamiento, la provocación traviesa, la parodia, sino también la de gozar una y otra vez, y del modo más intenso, de triunfos y victorias. El adulto libera su corazón del temor y disfruta nuevamente de su dicha, cuando habla de ellos. El niño los recrea, vuelve a empezar. La esencia del ju-

\footnotetext{
$4 \quad$ Otra perspectiva de lectura, como la de Graciela Tomassini (1995), anula toda vacilación e interpreta, no solo que se trata de "un crimen: la victimización de una niña por su tía", sino que además establece las razones que movilizarían a la tía en tanto victimaria: "exasperada por el alboroto de los juegos o por una presunta desobediencia" (p. 33).

5 En relación con la infancia como una de las formas de la insensatez, Pollock (2003) anota que el término "insania" en latín designaba "toda forma de insensatez" y se aplicaba "tanto al hombre maduro, esclavo de sus pasiones y lleno de vicios, como al infante, infans ('el que no habla')." (p. 22).
} 
gar no es un "hacer de cuenta que...", sino un "hacer una y otra vez", la transformación de la vivencia más emocionante en un hábito". (pp. 7879).

En estos cuentos no solo es la ley del "una y otra vez" la que vincula al juego con el dibujo animado, sino además el paso de la desgracia al humor por la vía del disparate.

La alegría singular que se desprende de estos relatos, es la que nace del irremediable fracaso, una alegría que no puede sino levantarse sobre un fondo de angustia. La lógica que los emparenta con el juego y con el dibujo animado, es aquella por la que recrean una y otra vez el "radical fracaso en que consiste lo cómico y en que consiste la vida" (Foix, 1965, p. 45). El humor de las expectativas frustradas es el del extravagante, el de aquel que sigue su camino con humildad, en el ejercicio de la paciencia, con el fracaso a cuestas. Si los personajes de estos cuentos son inocentes, lo son únicamente en el sentido en que Carlos Foix dice que "sin inocencia no hay comicidad; para ello es preciso buena fe, ánimo ingenuo, cierta pueril confianza, credulidad, inagotable esperanza" (p. 48). En la inagotable esperanza que nace del fracaso se dirime el carácter ingenuo o hu- milde, por lo tanto, humorístico, de estos seres extravagantes.

Ese destino nonsensical como ejercicio de la extravagancia en medio de la desgracia los vuelve de algún modo más reales, si entendemos la forma cómica de la vida como una sucesión de "esperanzas seguidas de cerca o de lejos por la frustración", como "una cadena de expectativas que concluyen en nada (en la nada cómica)" (Foix, 1965, p. 44). Por eso es que la tragedia no los lleva a hundirse en la profundidad del sentido sino a remontar el fracaso con humor, con desatino: habitan el sinsentido que les depara la desgracia en el extremo de la locura. Como haciendo de la desgracia un juego, no ven en la muerte más que una nada cómica, de la que siempre nace una nueva actualización de la esperanza: volver a hacer una y otra vez la gracia. Como un niño que inventa historias con sus juguetes, como en los dibujos animados, la muerte nunca es el final: el juego continúa. No importa lo que pasa, lo que interesa es la continuidad del relato, así esto signifique que los personajes se vuelvan muñecos.

En el final que no es el fin, Celestina sigue dando vueltas al compás de la música; Clodomira sigue planchando en tanto sus hijos, que ahora son muñecos, podrán lanzarse una y otra vez por la ventana; Eponina juega a vestir a su hijo-muñeco según recomiendan las revistas de moda (¿no hay ya en esos nombres un sesgo de irrealidad, una impronta de humor, una huella del juguete $\left.{ }^{6}\right)$. Como si dijeran: la vida (cómica) sigue. "iQué risa!» podría ser, como en el relato "El vestido de terciopelo", de La furia y otros cuentos, el latiguillo final de cada una de ellas, semejante al «eso es todo, amigos» de aquellos dibujitos animados: una frase que, sin decir nada, junta un destello de felicidad con una cierta angustia, la esencial mezcla de desazón y alegría que anuncia el final, cada vez que el pretendido cierre no es otra cosa que la promesa de un recomienzo. ¿No tiene acaso nuestra vida la forma de ese «todo» del dibujo animado, esa actualización permanente de una espera y un fracaso que, indefectiblemente, no dejará de hacernos reír?

Ese «qué risa» no es el de la diversión; acarrea un cierto sabor amargo, una cierta resignación o impavidez: un modo de abrazar un destino que no puede sino ser humorístico, a fuerza de fracaso.

La muñeca cifra la impasibilidad sin emoción que caracteriza al relato. Habría que leer esa indiferencia del sentido según

$6 \quad$ Desde una perspectiva diferente sobre el humor, Noemí Ulla (1989) -entre otros- se refirió al carácter chistoso, irónico o paródico de los nombres en Silvina Ocampo (p. 391). 
la consigna de no buscar, ni encontrar, sólo perder el sentido. Signo de una salida extrema, la muñequización condensa el acto involuntario de perderse en el instante de gracia: salida del sentido, salida del tiempo, salida de la humanidad. La coda cristaliza en un dibujo perpetuo el perder, sólo perder como destino del cuento-viñeta. Abandonado por el tiempo, el instante de gracia es el de la pura pérdida, donde nada pasa, más que el puro pasar de la muñeca sobre la caja de música.

A la pregunta por la insensatez de la aparición de un dibujo risueño junto a la trágica muerte de la nena, se añade ahora esta otra: ¿cómo es posible que de Celestina perdure la imagen, en apariencia feliz, de la muñeca y su danza? La gracia por la que las formas se vuelven plásticas hace que en esas imágenes destelle, aún en medio de la desgracia, una alegría singular. El estremecimiento sin emoción que afecta a los cuentos de Viaje olvidado se define bien según la fórmula que usa Lacan para hablar de lo que ocurre en la obra de Carroll: "Allí se discierne -dice- que sin valerse de ninguna perturbación, puede producirse malestar, pero que de este malestar se desprende una alegría singular" (1966). Tanto el dibujo de los moños, florecimientos y soldaditos, como el del mero estar ahí, imperturbable, de la muñeca, producen un efecto de inquietud por el que no sin incomodidad uno llamaría a estas: «imágenes felices». En todo caso, no se trata de una alegría cualquiera; si se desprende de ellas, es innegable, un cierto brillo, también arrastran una densidad incómoda: una alegría singular, que es como decir, una alegría inquietante. En la superficie de la insensatez, desentendido de la razón, destella un dibujo, un color, una forma, con la gracia del sinsentido.

Los personajes y las voces de Viaje olvidado, sustraídos del sentido y de sí mismos, ven el mundo de cabeza y juegan con sus formas como con una plastilina. Así es como su «alegría singular» es la de la sinrazón, la locura de hacer con la desgracia un juego. Así, sin perturbación, sin emoción, miran las madres a sus hijos muertos como si fueran muñecos de trapo. De la caída de sus hijos por la ventana, Clodomira ve la plasticidad del salto acrobático, lo mismo que si viera papelitos de colores tirados al viento, pero no ve su humanidad a punto de estrellarse contra el suelo.

Un día no sentían ya el frío de la tarde sobre los brazos desnudos. Parados en el borde de una ventana del tercer piso, dieron un salto glorioso y envueltos en un saludo cayeron aplastados contra las baldosas del patio. Clodomira, que estaba planchando en el cuarto de al lado, vio el gesto maravilloso y sintió, con una sonrisa, que de todas las ventanas se asomaban millones de gritos y de brazos aplaudiendo, pero siguió planchando. (Ocampo, 2005, pp. 83-84).

Esa salida del ser, del sentido, los congela en un instante de gracia que les confiere un atributo plástico. «Volverse otros» es aquí volverse muñecos, por obra del traslado sin movimiento hacia el lado de lo imposible, que de pronto se torna lo real. Asimismo, el hijo de Eponina se vuelve un muñeco vestido de raso, guardado en un cajón:

Eponina abrió el cajón y vio a su hijo muerto, al que más había ambicionado subir sobre sus faldas: ahora estaba dormido sobre el pecho de uno de sus vestidos más viejos, en busca de su corazón.

La familia enmudecida de horror en el umbral de la puerta, se desgarraba con gritos intermitentes clamando por la policía. Habían oído todo, habían visto todo; los que no se desmayaban, estaban arrebatados de odio y de horror.

Eponina se abrazó largamente a Ana con un gesto inusitado de ternura. Los labios de Eponina se movían en una lenta ebullición: "Niño de cuatro años vestido de raso de algodón color encarnado...". (pp. 62-63).

En el instante en el que les sobreviene la desgracia, los personajes se salen de sí al extremo 
de volverse criaturas sin humanidad, sin edad, sin emoción, aunque conserven todavía su semejanza con las personas de carne y hueso. Con frecuencia, en los cuentos de Silvina Ocampo -y no sólo los de Viaje olvidado- hay muñecos que cobran vida y personas que parecen muñecos. Además de Celestina, que se vuelve muñeca de cajita musical y del hijo de Eponina, vuelto muñeco de raso; la protagonista de "Paisaje de trapecios", Charlotte, es descripta como una muñeca de trapo, de piel rosada, brazos de algodón y cuerpo endeble, siempre cayéndose (que parece cobrar vida momentáneamente cuando alguien se enamora de ella); la nena Fulgencia, de "Día de santo", es perseguida por una muñeca sin ojos; el nene de "El vendedor de estatuas", Tirso, recuerda a un muñeco maldito que atormenta al hombre de las estatuas; el enfermo de "Diorama" "juega" a que una mujer inexistente lo cuida, y se dirige a ella como a una muñeca invisible. En los muñecos se cifra el encuentro de persona y cosa: son cosas que parecen personas.
La muñequización de los personajes cifra el gesto por el que la narración se precipita hacia la lógica del dibujo animado. Es que su «locura inimputable» reside en el dibujo, en el modo en que pintan de gracia la desgracia para sacarla de quicio. Ese dibujo es indiferente al sentido: ven la gracia de la imagen, sin preocuparse por el sentido. Tal ecuación parece jugar a invertir aquel chiste de Carroll: "cuida del sentido, y el sonido se cuidará de sí mismo" (en el capítulo VI de Alicia en el país...). Se trataría, en estos cuentos de Ocampo, de atender al dibujo, a la superficie, y dejar el sentido librado a sí mismo. "Ni el texto ni la intriga recurren a resonancias de significaciones llamadas profundas. No se evoca allí ni génesis, ni tragedia, ni destino -reflexiona Lacan sobre el nonsense de Carroll, aunque bien podría pensarse lo mismo sobre estos cuentos de Ocampo, y luego se pregunta-, entonces ¿cómo esta obra hace tanta mella?" (1966). De los relatos que nos ocupan, hace mella el mero despropósito nunca escindido de la potencia de las imágenes, la salida hacia lo real por obra del dibujo. Luego de arriesgar que Carroll anticipa las tiras de historietas, Lacan (1966) afirma:

De las imágenes, se hace un puro juego de combinaciones, pero, ¿qué efectos de vértigo se logran entonces?

Combinaciones en las que se traza el plano de todo tipo de dimensiones virtuales, pero que son aquellas que dan acceso a la realidad, finalmente la más segura, la de lo imposible que de pronto se vuelve familiar.

¿Cómo acceder a la sinrazón de lo real, al sentido sin juicio, sin moral? En el instante en que la vida se torna una cuerda floja, habitar el mundo equivale, irremediablemente, a hacerse funámbulo. Esto es, volverse ajeno al sentido y residir sobre la superficie de las cosas como sobre una cuerda floja. Salirse de sí (del sentido) para ocuparse en la pirueta y habitar la plasticidad de las formas: el hacer una y otra vez del juego. 


\section{Referencias}

Balderston, D. (1983). Los cuentos crueles de Silvina Ocampo y Juan Rodolfo Wilcock. Revista Iberoamericana, (125), 743-752.

Benjamin, W. (1989 [1974]). Escritos. La literatura infantil, los niños y los jóvenes. (J. J. Thomas, trad.). Buenos Aires: Nueva visión.

Bianco, J. (1937). Viaje olvidado. En Ficción y reflexión (pp. 148-149). México: Fondo de Cultura Económica.

Cueto, S. (2008). “Chesterton o el nonsense” y "Lear”. En: Otras versiones del humor (pp. 7-28; 29-52). Rosario: Beatriz Viterbo Editora.

Dickinson, E. (2011). 435. En Emily Dickinson: Oblicuidad de luz (95 poemas) (R. Costa Picazo, trad.). (p. 116). Valencia: Editorial Universitat de Valencia.

Dickinson, E. (2013). 435. En Poemas (S. Ocampo, trad.). (p. 125). Buenos Aires: Tusquets.

Foix, J. C. (1965). Qué es lo cómico. Buenos Aires: Columba.

Gagnebin, J. M. (2004). A criança no limiar do laberinto. En Infancia y Narración en Walter Benjamin (pp. 78-82). San Pablo: Editora Perspectiva.

Lacan, J. (1966). Homenaje a Lewis Carroll. Recuperado el 29 de septiembre de 2017, de http://www. ub.edu/las_nubes/archivo/15/nubesyclaros/textos/lacan.html

Ocampo, V. (1937). Viaje olvidado. Sur, 7, 118-121.

Ocampo, S. (2005). Viaje olvidado. Buenos Aires: Emecé.

Pizarnik, A. (1994). Dominios ilícitos. En: C. Piña, Obras Completas: Poesía completa y prosa selecta. Buenos Aires: Corregidor.

Podlubne, J. (2011). Escritores de Sur. Los inicios literarios de José Bianco y Silvina Ocampo. Rosario: Beatriz Viterbo Editora-Universidad Nacional de Rosario.

Podlubne, J. (2013). La visión de la infancia en los cuentos de Silvina Ocampo. Confluenze. Rivista di studi iberoamericani. Dipartimento di Lingue, Letterature e Culture Moderne, Università di Bologna, 5(2), 97-106.

Pollock, J. (2003). ¿Qué es el humor? Buenos Aires: Paidós.

Sánchez, M. (1991). Las reglas del secreto. Buenos Aires: Fondo de Cultura Económica. 
Stewart, S. (1989). Nonsense: Aspects of Intertextuality in Folklore and Literature. Baltimore/Londres: The John Hopkins University Press.

Tomassini, G. (1995). El espejo de Cornelia. La obra cuentística de Silvina Ocampo. Buenos Aires: Plus Ultra.

Ulla, N. (1989). Silvina Ocampo. En: Historia de la literatura argentina. Buenos Aires: CEAL. 